\author{
SONIA PAŹ-DYDERSKA ${ }^{1}$, MARCin K. DYDERSKI ${ }^{1}$, ANDRZEJ M. JAGODZIŃSKi ${ }^{1,2}$ \\ ${ }^{1}$ Instytut Dendrologii PAN \\ Parkowa 5, 62-035 Kórnik \\ ${ }^{2}$ Katedra Łowiectwa $i$ Ochrony Lasu \\ Wydziat Leśny i Technologii Drewna \\ Uniwersytet Przyrodniczy w Poznaniu \\ Wojska Polskiego 71D, 60-625 Poznań \\ E-mail: sdyderska@man.poznan.pl \\ mdyderski@man.poznan.pl \\ amj@man.poznan.pl
}

\title{
OCHRONA KLIMATU KOSZTEM RÓŻNORODNOŚCI BIOLOGICZNEJ? ŚRODOWISKOWE I SPOŁECZNE KONSEKWENCJE WYDOBYCIA LITU NA PUSTYNI ATAKAMA
}

\section{WSTEP}

W obliczu nasilajacych się zmian klimatycznych na całym swiecie organizowane sa strajki klimatyczne. Wynika to $z$ coraz dotkliwszych dla ludzi skutków tych zmian, takich jak coraz bardziej upalne lata czy częściej występujace ekstremalne zjawiska pogodowe. Jednocześnie wzrasta świadomość społeczeństwa dotycząca potrzeby natychmiastowych i skutecznych regulacji prawnych dotyczacych ochrony klimatu. Jedna z naturalnych konsekwencji wzrostu świadomości jest zwiększone zapotrzebowanie na rozwiąania proekologiczne możliwe do zastosowania ad hoc, nawet na poziomie jednostki. Wśród możliwych rozwiązań pozwalających na ograniczenie emisji dwutlenku węgla pochodzacego ze spalania paliw kopalnych, gazu będącego jednym $z$ najważniejszych gazów cieplarnianych, jest zamiana pojazdów spalinowych na elektryczne. Wykorzystanie energii elektrycznej pochodzącej $Z$ odnawialnych źródeł stanowi jedna $Z$ wielkich nadziei w walce ze zmianami klimatycznymi. Niestety, wyobrażenia dotyczace licznych korzyści wypływajacych $z$ takich zmian uwzględniaja głównie etap korzystania $z$ pojazdu, nie skupiając się na procesie jego produkcji. Do budowy samochodów elektrycznych potrzebne sa bowiem znaczne ilo- ści litu, pierwiastka, którego największe na świecie rezerwuary znajduja się na pustyni Atakama w północnym Chile. Wpływ wydobycia litu na ten wrażliwy na zmiany obszar pozostaje słabo udokumentowany. Nie ulega jednak wątpliwości, że przemysł wydobywczy wywiera negatywny wpływ na ten ekosystem unikatowy w skali świata.

\section{WYDOBYCIE LITU. CZY CHRONIĆ KLIMAT KOSZTEM RÓŻNORODNOŚCI BIOLOGICZNEJ?}

Chile jest w posiadaniu jednych $z$ największych zasobów i zarazem największym producentem litu na świecie. Blisko połowa jego globalnych zasobów jest zlokalizowana na Salar de Atacama. Szacuje się, że zgromadzone tam zasoby litu moga wynosić od 3 do nawet 35 megaton (VIKSTRÖM i współaut. 2013), podczas gdy, w zależności od przyjętej metodyki, światowe zasoby szacuje się na około 39 megaton (GRUBER i współaut. 2011). Należy jednak zauważyć, że wyniki poszczególnych predykcji znaczaco się od siebie różnią. Scenariusz zakładajacy największy możliwy popyt na lit na świecie do 2100 r. nie przekracza 20 megaton i wielu naukowców (GRUBER i współaut. 2011, KESLER i współaut. 2012) zapewnia, że obawy dotyczace niewystarczających zasobów

Słowa kluczowe: Atakama, baterie, Chile, lit, samochody elektryczne

*Druk pracy był finansowany ze środków Instytutu Dendrologii Polskiej Akademii Nauk. 
litu sa nieuzasadnione. Biorac jednak pod uwage ponad dziesięciokrotne różnice między szacunkami w zasobach litu na samym tylko Salar de Atacama, zapewnienia te nie sa w pełni przekonujące. Ponadto, prognozy nie uwzględniaja środowiskowych kosztów wydobycia litu. Nie wiadomo też, na ile jego wydobycie $z$ poszczególnych miejsc jest możliwe i opłacalne.

Prognozowany wzrost zużycia tego pierwiastka w najbliższych dekadach stanowi silny bodziec dla zagranicznych inwestorów, na przykład korporacji ze Stanów Zjednoczonych, Chin czy Rosji. Lit wykorzystywany jest bowiem nie tylko $w$ produkcji samochodów elektrycznych, które nie sa jeszcze szeroko rozpowszechnione, ale również $\mathrm{w}$ bateriach komputerów, telefonów komórkowych, a w przemyśle farmaceutycznym przy produkcji antydepresantów. Ponadto, $\mathrm{w}$ ostatnich latach baterie litowe znalazky nowe zastosowania, m.in. w produkcji zabawek, papierosów elektronicznych, urzadzeń medycznych, narzędzi ogrodniczych, rowerów elektrycznych i innych przenośnych urządzeń elektrycznych (BLOMGREN 2016). Jakkolwiek zastosowania te sa liczne, to dotycza jednak najczęściej urządzeń niewielkich rozmiarów. W przypadku samochodów wykorzystanie litu jest oczywiście dużo wyższe. Przykładowo, produkowane i sprzedawane obecnie modele Tesla $\mathrm{S}$ i Tesla X maja baterie rozmiarów $60-100 \mathrm{kWh}$, które umożliwiaja przebycie od 334 do 508 kilometrów. Zestawienie BLOMGRENA (2016) uwzględnia również samochody $z$ bateriami mniejszych rozmiarów (np. Mitsubishi I - $16 \mathrm{kWh}$, Smart Fortwo EV - 17,6 kWh, Chevrolet Spark - $19 \mathrm{kWh})$. Wiąże się to jednak $\mathrm{w}$ naturalny sposób $\mathrm{z}$ dużo mniejszym zasięgiem tych pojazdów (odpowiednio: $100 \mathrm{~km}, 109 \mathrm{~km}, 132 \mathrm{~km}$ ). Można przyjąć, że aby samochód był funkcjonalny, wymagana jest bateria o rozmiarach powyżej 30 $\mathrm{kWh}$. Umożliwia to przebycie około $150 \mathrm{ki}-$ lometrów (np. Mercedes B-Class Electric z bateria $28 \mathrm{kWh}-137 \mathrm{~km}$, Ford Focus EV $\mathrm{z}$ bateria $35,5 \mathrm{kWh}-160 \mathrm{~km})$. Na $1 \mathrm{kWh}$ przypada od 1,4 do $1,5 \mathrm{~kg}$ węglanu litu $\left(\mathrm{Li}_{2} \mathrm{CO}_{3}\right)$, co daje ponad 42 kilogramy litu na jeden samochód elektryczny. $\mathrm{Na}$ świecie jest około pięciu milionów samochodów elektrycznych, co stanowi nieco ponad 2\% wszystkich samochodów, ale ich liczba rośnie. W tym kontekście wyobrażenia dotyczące łagodzenia zmian klimatycznych przez promowanie i wykorzystanie samochodów elektrycznych muszą zostać zweryfikowane. Wydobycie koniecznego do ich budowy litu nie pozostaje bowiem bez wplywu na środowisko przyrodnicze.

\section{RÓŻNORODNOŚĆ PUSTYNI}

Choć mogłoby się wydawać, że w kontekście potencjalnych zysków środowiskowych (znaczne ograniczenie zużycia paliw kopalnych) warto poświęcić ten obszar, odbierany nierzadko jako miejsce cechujące się niska różnorodnością biologiczną (np. w porównaniu $z$ lasami tropikalnymi), $w$ istocie jest wręcz przeciwnie. Charakterystyka Atakamy sprawia, że jest to obszar wyjątkowy.

Średnie roczne opady atmosferyczne na pustyni Atakama różnią się $\mathrm{w}$ zależności od lokalizacji (Houston 2006). Najniższą średnia roczna ilość opadów z 24 kolejnych lat pomiarów w stacjach meteorologicznych odnotowano w Quillagua $(0,15 \mathrm{~mm})$ i Coya Sur $(0,4 \mathrm{~mm})$. Szczególny wpływ na panujące warunki ma Prąd Peruwiański, który przyczynia się do schładzania wilgotnych mas powietrza i powstawania mgieł - stad określanie Atakamy pustynia mglista (HousToN 2006). Drugim czynnikiem determinujacym panujący tu klimat jest lokalizacja w strefie zwrotnikowej. Nikłe opady to również efekt występowania naturalnych barier otaczajacych Atakamę: Andów od wschodu i Gór Domeyki od zachodu. Dodatkowo, lokalizacja na dużej wysokości (np. miejscowość San Pedro de Atacama - 2400 m n.p.m., gejzery El Tatio - 4320 m n.p.m.) czyni Atakamę miejscem niezwykłym pod wieloma względami (Ryc. 1).

Płaskowyż, na którym znajduje się pustynia, powstał $\mathrm{w}$ wyniku kilku zdarzeń $\mathrm{w}$ historii Ziemi (FuinT i współaut. 1993). Skorupa ziemska składa się $z$ będących w ciagłym ruchu płyt tektonicznych. Raz na miliony lat płyty tektoniczne zderzaja się ze soba, tworząc nowe pasma górskie. Chile znajduje się na pograniczu kilku płyt: kontynent położony jest na płycie południowoamerykańskiej, natomiast od strony Pacyfiku znajduja się płyty Nazca, kokosowa i pacyficzna (JORDAN i współaut. 1983). Najstarsze góry w Chile znajduja się na wybrzeżu Pacyfiku. Pod dłu-

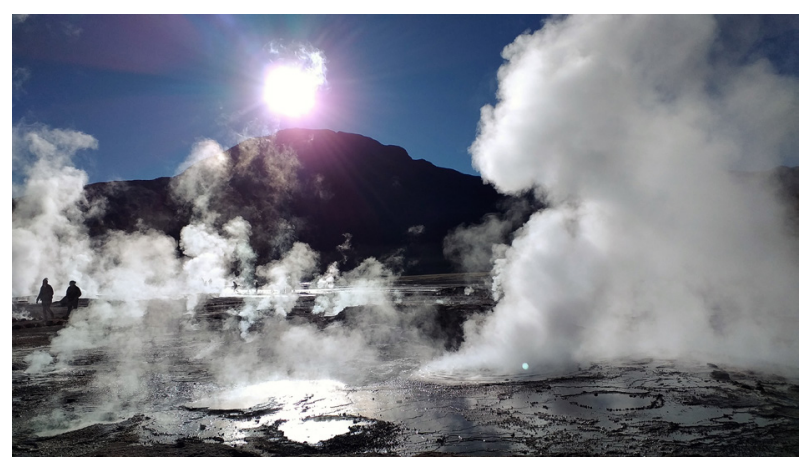

Ryc. 1. Gejzery El Tatio, położone na wysokości 4320 m n.p.m., stanowią cenny element georóżnorodności. Fot. S. Paź-Dyderska. 
gotrwałym wpływem wiatru i deszczu, ostre i wysokie skały erodowały w pył, który częściowo trafił do oceanu, a częściowo w głąb kontynentu (MORTIMER 1973). Kolejne zderzenie płyt tektonicznych przyczyniło się do wyniesienia Gór Domeyki, nazwanych tak na cześć inżyniera Ignacego Domeyki (18021889), polskiego geologa i wieloletniego rektora uniwersytetu w Santiago de Chile (PAULO 2002). Góry te również zaczęły erodować i sa obecnie dość łagodne, do czego przyczyniły się silne wiatry znad Atlantyku, niehamowane jeszcze wówczas przez mające dopiero powstać Andy. Sa one efektem ostatnich ruchów górotwórczych, tych samych, w trakcie których powstały Alpy, Himalaje czy Tatry. Sa stosunkowo młode, stą sa ostro zakończone nagimi szczytami. W tym czasie na skutek wypiętrzenia Andów doszło do wyniesienia osadów morskich, które wcześniej tworzyły góry nadbrzeżne i Góry Domeyki. W ten sposób powstały Góry Słone, w których znajduje się Dolina Księżycowa (Valle de la Luna). Z tego samego powodu na tym obszarze tak licznie występuja zróżnicowane minerały, w tym również sole (m.in. azotanowe i siarczanowe).

Pustynia zadziwia swoją różnorodnością (Ryc. 2). W zależności od wysokości, ukształtowania terenu i chemizmu gleby poszczególne obszary znacząco się różnią. W Dolinie Tęczowej (Valle del Arcoiris), ułożone warstwowo wielobarwne skały zwiazane z działaniem różnych czynników, stanowia znakomity przykład złożoności i zmienności procesów kształtujacych ten niezwykły obszar (Ryc. 3). Najstarsze, występujace u podnóży gór frakcje czerwone to gliny powstałe ze skał osadowych $z$ czasów formowania się Gór Domeyki. Szare skały to nagromadzone pyły wulkaniczne. Występujace zaś na szczytach formacji skalnych frakcje zielone to efekt aktywności wód geotermalnych i osadzania się złożonych pod wzglę-

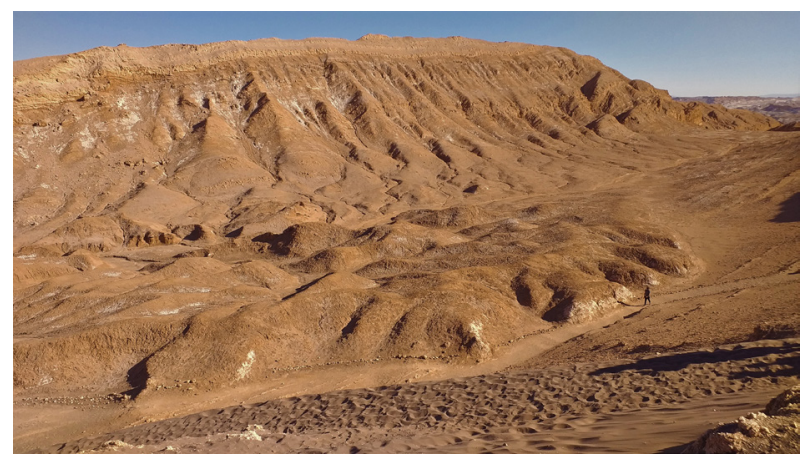

Ryc. 2. Pustynia Atakama jest bardzo zróżnicowana pod względem ukształtowania terenu - przykładem jest Dolina Księżycowa (Valle de la Luna). Fot. S. Paź-Dyderska.

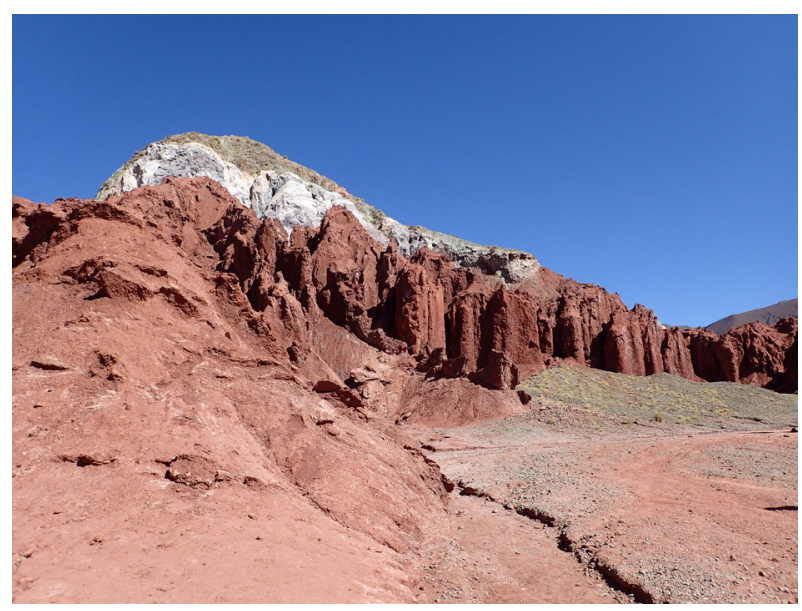

Ryc. 3. Warstwowy układ skał w Dolinie Tęczowej (Valle del Arcoiris). Fot. M. K. Dyderski.

dem budowy chemicznej minerałów. Występuje tam od kilku do kilkunastu gatunków roślin, głównie przystosowanych do suszy i nasłonecznienia krzewów, np. Acantholippia deserticola (powszechnie używa się nazwy Rica rica pochodzącej $z$ języka keczua, nawiazujaccej do przyjemnego smaku i aromatu jej liści) (Ryc. 4). Rośliny Atakamy charak-

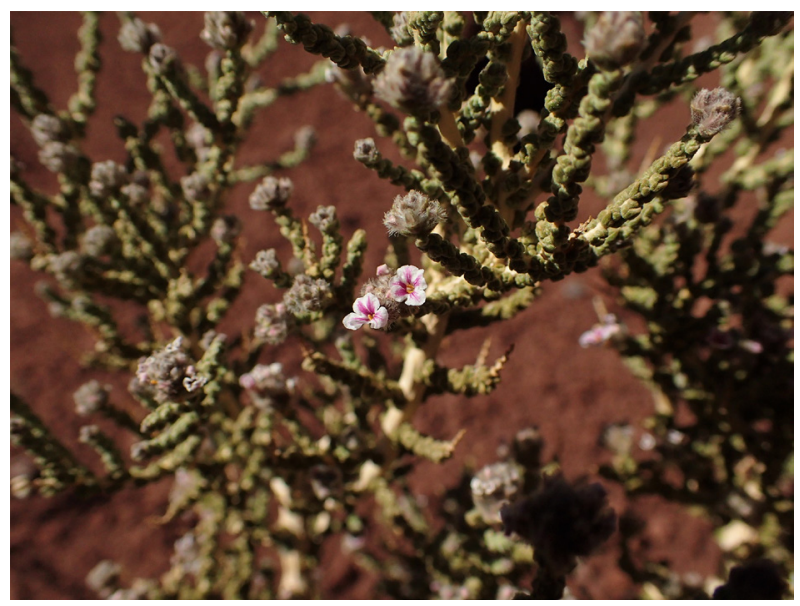

Ryc. 4. Acantholippia deserticola to gatunek szeroko wykorzystywany ze względu na smaczny, orzeźwiajacy smak i aromat liści. Fot. M. K. Dyderski.

teryzuje powolne tempo wzrostu oraz małe, grube i pokryte woskiem liście lub kolce uniemożliwiajace nadmierna transpirację (Ryc. 5). Regiony Altiplano (płaskowyżu) i El Tatio (gejzerów) również charakteryzują się dużym zagęszczeniem roślinności. Można tu zaobserwować wiele okazów rzadkich, ściśle wyspecjalizowanych gatunków obejmujacych m.in. rodzaje Festuca, Stipa czy Azorella. Bogactwo gatunkowe roślin jest jednak stosunkowo niskie. Dostęp do wody i obecność roślin na powierzchni pustyni umożliwia na- 


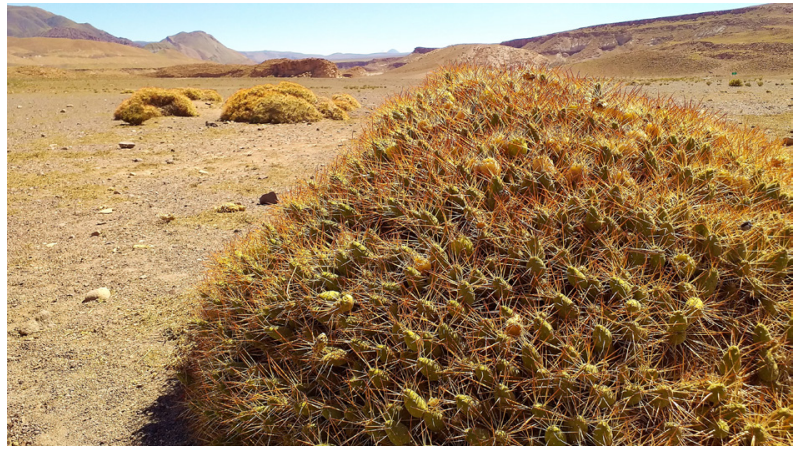

Ryc. 5. Opuntia conoidea stanowi przykład gatunku wysoce wyspecjalizowanego do życia w pustynnych warunkach. Fot. S. Paź-Dyderska.

tomiast występowanie $\mathrm{w}$ tym regionie wielu gatunków zwierząt.

Najłatwiej zaobserwować tu wikunię andyjska (hiszp. Vicuña, łac. Vicugna vicugna), gatunek roślinożernego ssaka $\mathrm{z}$ rodziny wielbładowatych, ważącego około 40 kilogramów (Ryc. 6). Wikunie sa dzikimi przodkami udomowionych alpak (Ryc. 7). Często stanowia cel kłusowników ze względu na właściwości swojego futra. Jego włókna sa niezwykle cienkie i delikatne, maja średnice $12 \mu \mathrm{m}$ (dla porównania średnica włókien kóz kaszmirowych wynosi od 14 do $19 \mu \mathrm{m}$, a polskiej owcy nizinnej od 24 do $37 \mathrm{\mu m})$. Wikunia produkuje jednak tylko około $0,5 \mathrm{~kg}$ wełny rocznie. $Z$ tych względów wełna wikuni jest jedna $z$ najdroższych na świecie: szalik $\mathrm{z}$ jej wełny może kosztować nawet ponad 2000 USD. Niestety, ze względu na długa ciążę (11 miesięcy), kłusownictwo i drapieżnictwo, wzrost liczebności populacji wikuni jest ograniczony i zachodzi bardzo wolno. Innym gatunkiem, który stosunkowo łatwo zobaczyć, jest nibylis andyjski (hiszp. Zorro culpeo, łac. Pseudalopex culpaeus). Jest nie-

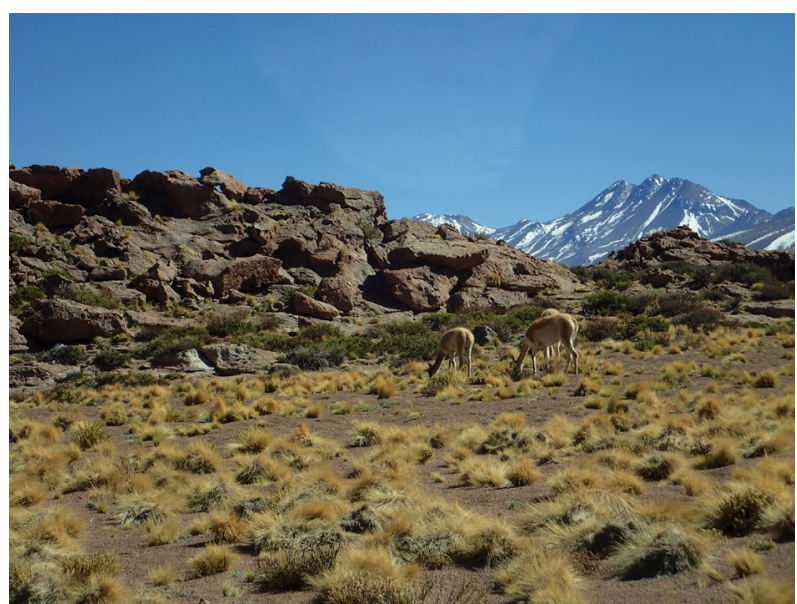

Ryc. 6. Wikunie andyjskie w regionie Lagunas A1tiplánicas. Fot. M. K. Dyderski.

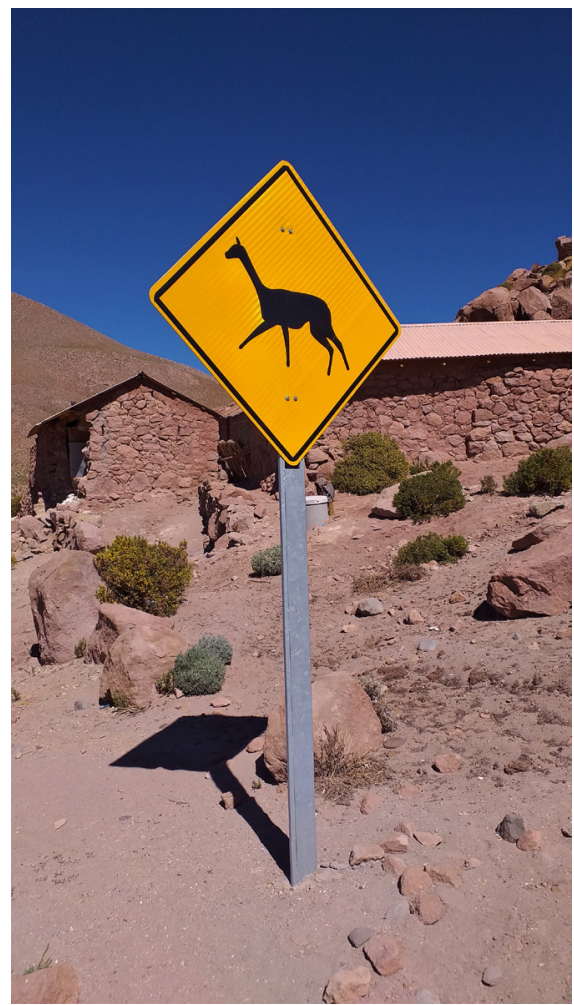

Ryc. 7. Populacje wielbłądowatych (dzikich wikuni i gwanako oraz udomowionych alpak i lam) sa bardzo liczne. Fot. S. Paź-Dyderska.

co wieksszy od lisa rudego: mierzy do 115 $\mathrm{cm}$ długości i waży do $12 \mathrm{~kg}$. Zamieszkuje zróżnicowane środowiska, przez co można go obserwować zarówno w górach, na otwartej pustyni, jak i w zaroślach. Nieco trudniej dojrzeć kryjące się w norach wśród skalistych terenów płaskowyżu wiskacze górskie (hiszp. Vizcacha, łac. Lagidium viscacia). Sa to gryzonie nieco przypominajace króliki (o wysokości do $40 \mathrm{~cm}$ ), jednak bezpośrednio $z$ nimi niespokrewnione. Dzięki prowadzonym zabiegom ochronnym, liczba osobników tego rzadkiego gatunku wciąż rośnie. Nie można tego niestety powiedzieć o najrzadszym gatunku płaskowyżu, nandu plamistym (hiszp. Suri albo Nandú, łac. Pterocnemia pennata). Ten niemal metrowej wysokości nielot może w biegu osiagać prędkość nawet $60 \mathrm{~km} / \mathrm{h}$. Zamieszkuje tereny otwarte, np. murawy wysokogórskie położone ponad $3000 \mathrm{~m}$ n.p.m. Niestety, jest to gatunek wystepujacy nielicznie, zagrożony wyginięciem. Mimo tego, obszar płaskowyżu charakteryzuje się stosunkowo dużą różnorodnością biologiczna na tle pustynnego krajobrazu. Przykładowo, w Dolinie Księżycowej położonej w Górach Słonych krajobraz zdecydowanie się różni. Występuja tam jedynie pojedyncze okazy kilku gatunków roślin niewielkich rozmiarów, dominuja bowiem charakterystyczne dla tego 
regionu układy piasku, surowych skał i osadzającej się soli.

\section{ZAGROŻENIA}

Sole $\mathrm{i}$ inne minerały $z$ Gór Słonych już w czasach sprzed Imperium Inków stanowiły środek płatniczy dla ludów osiedlających się na tym nieprzyjaznym obszarze. Również obecnie surowce mineralne stanowia jeden z ważnych elementów gospodarki regionu, szczególnie lit i miedź. Wydobycie litu związane jest $z$ wypompowywaniem wód głębinowych i odparowywaniem ich w osadnikach. Stanowi to znaczne zagrożenie dla tego niezwykłego ekosystemu. Szczególnie narażone sa nieliczne mokradła górskie, solniska i podziemne jeziora determinujace występowanie flory i fauny, w 60\% endemicznej. Przykładowo, na solnisku Laguna Chaxa występuja trzy gatunki flamingów: flaming krótkodzioby (Phoenicoparrus jamesi), chilijski (P. chilensis) i andyjski (P. andinus). Miejsce to stanowi jedna $Z$ głównych atrakcji turystycznych regionu (Ryc. 8). Flamingi gina jednak wskutek zatrucia, żerując w przemysłowych osadnikach, które mylą $z$ naturalnymi solniskami. Coraz częściej też opuszczają Atakamę. Jest to niechlubny przykład bezpośredniego negatywnego wpływu wydobycia minerałów na lokalna przyrodę. Biorac jednak pod uwage fakt, jak złożone powiazania i mechanizmy determinuja funkcjonowanie ekosystemów, wpływ pośredni przemysłu wydobywczego na ten cenny region jest dalekosiężny $i$ trudny do zrekompensowania. Dodatkowy problem stanowi jego bardzo słabe rozpoznanie.

Kolejny dowód na dużą wartość przyrodniczą i naukową, ale również na wrażliwość ekosystemu Atakamy, stanowi jej specyficzna, halofilna flora (zwiazana ze środowiskiem zasolonym). Pustynne siedliska zostały zajęte przez silnie wyspecjalizowane rośliny, co umożliwiło wykształcenie i trwanie różnorodnych typów roślinności (PRADO i współaut.

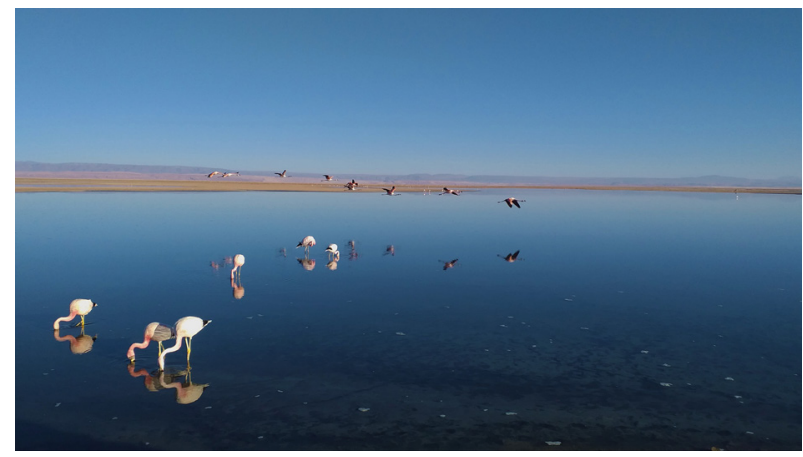

Ryc. 8. Flamingi żerujące w jeziorze Laguna Chaxa. Fot. S. Paź-Dyderska.

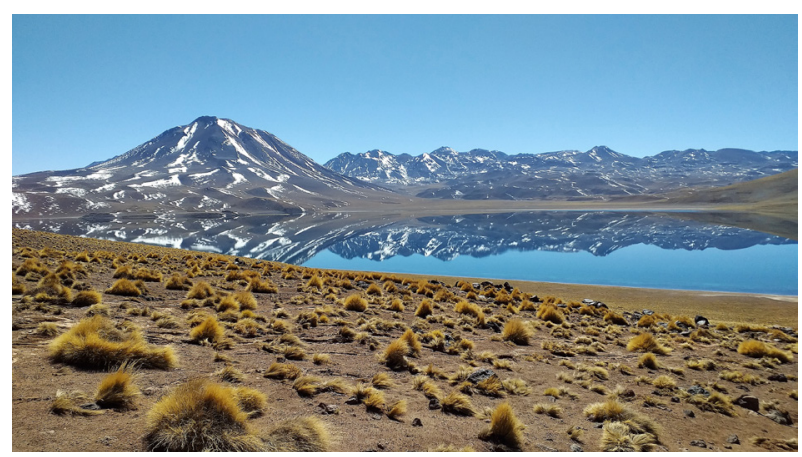

Ryc. 9. Na pierwszym planie charakterystyczna Festuca ortophylla, na drugim jeden $z$ nielicznych zbiorników wodnych na chilijskim płaskowyżu Jezioro Miscanti w regionie Lagunas Altiplánicas. Fot. S. Paź-Dyderska.

1993). Na niższych wysokościach występuja ziołorośla i krzewinki przystosowane do słonych gleb i suszy. Wyżej przeważaja niskie krzewy, najwyżej zaś puna - wysokogórska murawa, $z$ dominacja charakterystycznej żółtobarwnej kostrzewy Festuca ortophylla (Ryc. 9), tworzacej widoczny $z$ daleka element krajobrazu (GEBICA 2010). W poszczególnych miejscach można odnaleźć rzadkie gatunki, których niska liczebność często jest wynikiem niezrównoważonego wykorzystania przez człowieka. Przykładowo, pokrywajaca niegdyś całe zbocza gór Azorella compacta można zaobserwować obecnie jedynie na nielicznych, oddalonych od szlaków turystycznych stanowiskach (WICKENS 1995). Ta przypominajaca stos poduszek roślina jest długowieczna (wiek niektórych okazów szacuje się na ponad 3000 lat), ale rośnie bardzo powoli, od 1 do $5 \mathrm{~mm}$ rocznie (Ryc. 10). Rdzenni mieszkańcy Andów wykorzystywali tę roślinę do przygotowywania naparów $\mathrm{i}$ nalewek stosowanych w leczeniu m.in.

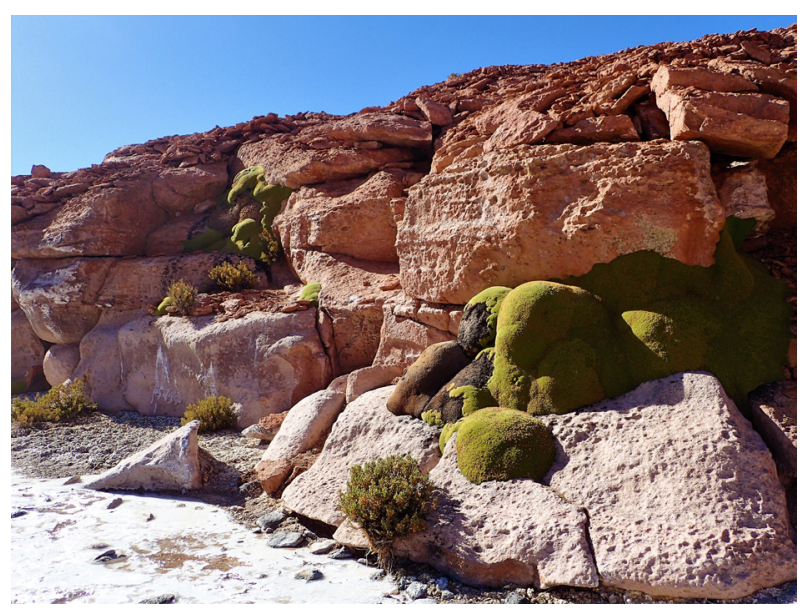

Ryc. 10. Jedno $z$ nielicznych stanowisk Azorella compacta. Fot. M. K. Dyderski. 


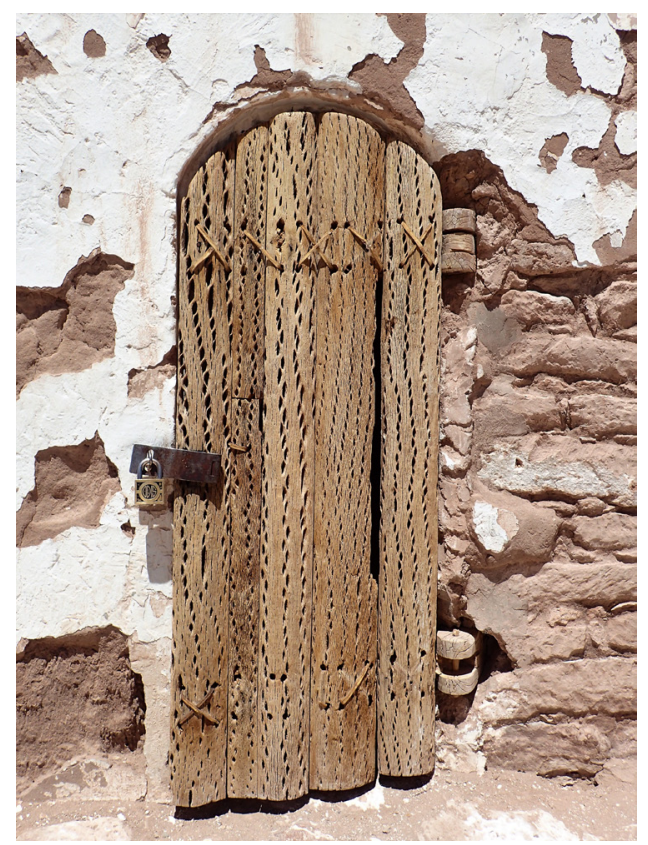

Ryc. 11. Drewno kaktusa dawniej było wykorzystywane m.in. w budownictwie oraz do produkcji mebli. Na zdjęciu drzwi $z$ Echinopsis atacamensis w zabytkowym kościele w miejscowości Toconao. Fot. M. K. Dyderski.

chorób żołądka, bóli menstruacyjnych czy obrzęku prostaty. W przeszłości była również wykorzystywana jako rozpałka i wysokoenergetyczny opał. Innym, nadmiernie eksploatowanym gatunkiem był cardón (Echinopsis atacamensis), wysoki kolumnowy kaktus o charakterystycznie włóknistym, atrakcyjnym drewnie (Ryc. 11) wykorzystywanym w budownictwie oraz do produkcji mebli i ozdób (ORTEGa-BAes i współaut. 2010). Z tego powodu dziś występuje rzadko, w najbardziej niedostępnych obszarach Atakamy. Choć nietrudno zrozumieć, że w przeszłości osadnicy tego nieprzyjaznego regionu wykorzystywali wszystkie dostępne zasoby naturalne, to dzisiejsze dalsze korzystanie $\mathrm{z}$ tak rzadkich gatunków, np. do produkcji pamiątek, stanowi duży problem. Na szczęście zarówno wśród mieszkańców regionu, jak i turystów, wzrasta poziom świadomości ekologicznej, co może stanowić kolejny krok w kierunku zrównoważonego wykorzystania tego cennego ekosystemu.

\section{OCZY ZIEMI, CZYLI ASTRONOMIA NA ATAKAMIE}

Unikatowe warunki przyrodnicze panujace na Atakamie sa atrakcyjne nie tylko dla turystów. Jest to także najważniejszy na świecie obszar umożliwiający prowadzenie zaawansowanych badań astronomicznych. Ponad 300 bezchmurnych nocy w roku i nieprzeciętnie przejrzysta atmosfera stanowia o doskonałych warunkach do prowadzenia badań. Już teraz na Atakamie znajduje się największy teleskop do badania fal milimetrowych $\mathrm{i}$ submilimetrowych na świecie, $z$ czułością i rozdzielczością dotąd niemożliwa do uzyskania. Ten teleskop jest znany jako ALMA (ang. Atacama Large Millimeter/submillimeter Array). Dzięki niezwykłym możliwościom poznawczym ALMA nazywany jest oczyma Planety, a Chile - astronomiczna stolica świata. Nie bez przyczyny! Szacuje się, że w 2022 r. w Chile zlokalizowane będzie 70\% światowej infrastruktury astronomicznej. Ponadto, Atakama jest jednym $z$ niewielu obszarów na świecie umożliwiajacych symulację warunków panujących na Marsie (QUINN i współaut. 2005, PARRO i współaut. 2011). Przykładowo, NASA wykorzystuje Atakame do testowania Mars Rovera, pojazdu mającego znaleźć zastosowanie $\mathrm{w}$ badaniach kosmicznych. Ekstremalnie niska wilgotność powietrza i wysokie temperatury stanowia znakomite warunki dla wielu naukowców próbujaccych odtworzyć warunki panujace na Marsie. Prowadzi się tu również liczne badania archeologiczne. Atakama jest zatem miejscem cennym naukowo, przyrodniczo i turystycznie. Należy podkreślić, że te trzy aspekty wartości Atakamy przenikaja się i uzupełniaja. Tymczasem, ingerujący $\mathrm{w}$ chwiejna równowage pustynnego ekosystemu przemysł wydobywczy w znacznym stopniu zagraża poszczególnym gatunkom, i tak już narażonym, choćby ze względu na postępujące zmiany klimatyczne. Co więcej, naraża na niebezpieczeństwo również cała sieć powiązań rządzących tym ekosystemem.

\section{OCHRONA PRZYRODY A POLITYKA W CHILE}

Problematyka wydobycia litu w miejscu tak cennym nie dotyczy jednak wyłacznie kwestii ochrony klimatu i różnorodności biologicznej. Ważny jest również aspekt społeczno-ekonomiczny. Czymś, co w dużej mierze może wpłynać na dalsze losy chilijskiego przemysłu wydobywczego sa protesty Chilijczyków, które wybuchły w stolicy Chile w październiku 2019 r. i błyskawicznie objęły cały kraj. Choć wiele mediów jako powód krwawo tłumionych protestów podawało podwyżke cen biletów metra, to przyczyna protestów była dużo bardziej złożona.

Chilijczycy wyszli na ulice zmęczeni trzydziestoma latami rosnacych nierówności społecznych. Zdecydowana większość obywateli jest zmuszona utrzymywać się $z$ niewystarczajacej do zaspokojenia podstawowych potrzeb pensji minimalnej. Jest ona niższa niż w Polsce (301 tys. CLP, 1494 PLN), 
natomiast ceny produktów sa tam około półtora raza wyższe. Chile jest też jedynym krajem na świecie, w którym woda pitna jest własnością prywatnej spółki. Ponadto, opieka zdrowotna i szkolnictwo wyższe sa niemal całkowicie sprywatyzowane. Obecny prezydent Chile, Sebastián Piñera $z$ majątkiem wartym 2,7 miliarda USD, jest jednym $z$ jego pięciu najbogatszych obywateli, a różnica między pensja minimalna a pensja parlamentarzystów (ponad 9349 tys. CLP, 46400 PLN) jest ponad 30-krotna. Poza postulatami socjalnymi, przedstawiano również oburzenie wobec nadal silnie zakorzenionego w społeczeństwie patriarchatu oraz braku poszanowania praw mniejszości seksualnych i etnicznych. Podnoszono także kwestie zwiazane $z$ ochrona środowiska, w tym nadmierny rozwój inwestycji w górnictwie, nieprzekładający się na poprawę warunków życia większości obywateli.

W kulminacyjnym momencie protestów na ulice Santiago wyszło ponad 1,5 miliona osób. Zdecydowana większość manifestacji miała charakter pokojowy, lecz ze względu na brutalność chilijskiej policji i służb specjalnych wysłanych do tłumienia protestów zginęło co najmniej 26 osób, a ponad 4900 osób zostało rannych. W tej sprawie przeprowadzono specjalny Raport Biura Wysokiego Komisarza Narodów Zjednoczonych ds. praw człowieka. Udokumentowanych zostało ponad 350 przypadków uszkodzeń wzroku, w tym wiele przypadków utraty oczu $z$ powodu wykorzystania przez mundurowych gumowych kul zawierajacych ołowiane rdzenie (w rzeczywistości jedynie 20\% gumy). Ponad 28000 osób zostało zatrzymanych. Łamano prawa człowieka - policja i wojsko torturowały i gwałciły zatrzymanych. W miastach wznoszono barykady. Doszło również do podpaleń i licznych zniszczeń lokali i budynków należących do wielkich korporacji był to wyraz sprzeciwu wobec gromadzenia ogromnego kapitału w rękach nielicznych, często zagranicznych firm, podczas gdy zdecydowana większość społeczeństwa nie dysponuje środkami koniecznymi do zaspokojenia podstawowych potrzeb. Dezinformacja medialna i rozpowszechnianie przez partię rzadzaca nieprawdziwego obrazu demonstracji, wprowadzenie przez prezydenta stanu wyjatkowego, brak woli rozmowy $z$ protestujacymi $z$ jego strony czy wprowadzenie godziny policyjnej, przyczyniły się do nasilenia protestów. Szczególnym rodzajem manifestacji sprzeciwu Chilijczyków wobec obecnej sytuacji w kraju był protest typu cacerola$z o-w$ trakcie godziny policyjnej, nie mogac protestować na ulicach, mieszkańcy stawali na balkonach czy w oknach mieszkań i rytmicznie uderzali łyżkami w garnki i patelnie, powodujac ogromny, słyszalny z dużej odległości hałas: „nie uciszycie nas”.

Momentem zwrotnym okazało się wywalczone przez protestujacych referendum konstytucyjne przeprowadzone w październiku ubiegłego roku. Biorac pod uwagę, że jednym $z$ głównych celów opracowywanej konstytucji jest nacjonalizacja górnictwa $i$ ulepszenie systemu ochrony środowiska, być może wydobycie litu zostanie ograniczone ze względu na walory przyrodnicze i naukowe pustyni Atakama. Stanowiłoby to przełom w ochronie przyrodniczych, kulturowych i naukowych walorów pustyni, ale również $\mathrm{w}$ walce o godne warunki życia dla rdzennych mieszkańców tego obszaru.

\section{GŁOS MIESZKAŃCÓW ATAKAMY}

Mieszkańcy Atakamy aktywnie brali udział w protestach, m.in. blokujac drogi dojazdowe do miejsc wydobycia litu. Już od lat sprzeciwiaja się niszczeniu swojego regionu. Osoby wychowane na pustyni bardzo szanuja wodę jako źródło życia nie tylko własnego, ale również roślin i zwierząt (BABIDGE 2016). Biorac pod uwage trudne warunki panujace na pustyni nietrudno sobie wyobrazić, ̇̇e ich dalsze pogarszanie, związane ze zmniejszaniem dostępności wody, będzie stopniowo uniemożliwiało zamieszkiwanie tego obszaru nie tylko roślinom i zwierzętom, ale przede wszystkim ludziom, często pochodzacym $z$ rdzennych plemion zasiedlajacych te obszary od stuleci. Nieetyczne wykorzystanie wody przez przemysł wydobywczy prowadzi do niesprawiedliwości środowiskowej, jako że niezbędne do życia zasoby o silnie ograniczonej dosteppności wykorzystywane sa w celach przemysłowych na wielka skalę (ROMERO i współaut. 2012). Nie dziwi zatem, że każda dostrzegana zmiana w krajobrazie, np. zanikanie i tak nielicznych solnisk czy trawiastych zarośli, jest boleśnie odczuwana i stanowi powód do sprzeciwu wobec przemysłu wydobywczego. Co gorsza, choć zgodnie $z$ prawem przemysł nie może być zlokalizowany na obszarach chronionych, to i tak silnie na nie wpływa w sposób pośredni, przyczyniając się do degradacji unikatowych ekosystemów (ROMERO i współaut. 2012). Choć ogromny chilijski i międzynarodowy kapital jest inwestowany w przemysł wydobywczy na Atakamie, głos osób, które doskonale ją znaja i mogłyby się w znacznym stopniu przyczynić do bardziej zrównoważonego rozwoju regionu, jest uciszany i ignorowany (BABIDGE 2016).

Obecnie większość mieszkańców San Pedro de Atacama utrzymuje się $z$ turystyki (Ryc. 12). Ruch turystyczny jest jednak niewspółmierny do stopnia atrakcyjności regio- 


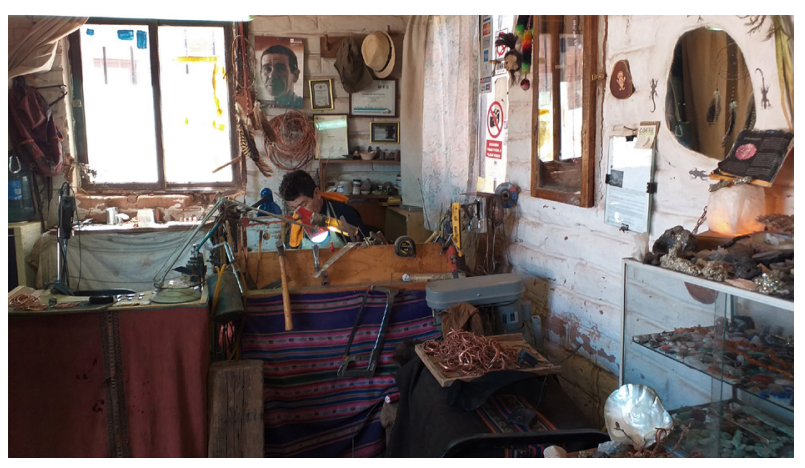

Ryc. 12. Warsztat rzemieślniczy w San Pedro de Atacama. Rzemieślnik na zdjęciu tworzy pamiątki $z$ miedzi $z$ recyklingu i lapis lazuli. Turystyka pozostaje głównym źródłem utrzymania dla wielu mieszkańców regionu. Fot. S. Paź-Dyderska.

nu, być może ze względu na niedostatecznie rozwiniętą infrastrukturę turystyczna (GEBICA 2010). Zyski $z$ turystyki nie stanowia więc konkurencji wobec zysków pochodzących $z$ przemysłu wydobywczego. $Z$ drugiej strony, przyjeżdżajacy $z$ całego świata turyści i naukowcy pełnia niejako role obserwatorów i kontrolerów. Gdyby Atakama nie stanowiła legendarnego wręcz celu turystycznego i nie charakteryzowałyby ja niespotykane gdzie indziej warunki do uprawiania nauki, pewnie wiele cennych miejsc i gatunków nie miałoby żadnych szans na przetrwanie. Należy jednak wziąć pod uwagę, że zmiany klimatyczne będa potęgowały i przyspieszały przewidywane zmiany, np. przez potęgowanie susz i przyspieszanie ewapotranspiracji (parowania wody) na obszarze Atakamy (DUARTE i współaut. 2019).

\section{PODSUMOWANIE}

Chcac zachować bogactwo regionu Atakamy dla przyszłych pokoleń należy dbać o rozpowszechnianie wiedzy i podnoszenie świadomości społecznej dotyczacej baterii litowych. Biorąc pod uwagę fakt, że niemal każdy $z$ nas korzysta $z$ nich na co dzień (a popyt na urzadzenia nadal rośnie), również na nas jako konsumentach ciąży odpowiedzialność. Warto zdawać sobie sprawę ze złożoności procesu produkcji baterii litowych i jego wpływu na środowisko, preferować produkty bardziej trwałe, wydłużać czas użytkowania poszczególnych urządzeń i pojazdów, przedkładać jakość nad ilość. Przede wszystkim nie należy jednak ulegać modom i zmieniać urządzeń tylko dlatego, że na rynku pojawił się nowy model telefonu. Częste wymienianie telefonów i innych urządzeń przyczynia się bowiem do degradacji cennych ekosystemów i do narażania rzadkich gatunków, np. flamingów, na wy- mieranie. Wymienione propozycje działań nie stanowia jednak rozwiazania opisanego tu złożonego problemu, a jedynie sposób na złagodzenie negatywnych skutków zmian $\mathrm{w}$ środowisku. Prowadzone sa badania nad opracowaniem technologii ponownego wpompowywania użytej wody do podziemnych zbiorników. Powoduje ona jednak drastyczny wzrost cen wydobycia litu i $z$ tego powodu nie jest obecnie wykorzystywana w przemyśle. Należałoby kontynuować prace nad zwiększeniem efektywności metodyki zwrotu wykorzystanej wody w celu zmniejszenia negatywnych skutków eksploatacji złóż, a także nad zwiększeniem możliwości recyklingu baterii litowych.

Można dojść do wniosku, że złoty środek pozwalający na zachowanie walorów Atakamy przy jednoczesnym ograniczeniu spalania paliw kopalnych nie istnieje. Podobnie jak w wielu innych przypadkach, bezpośrednia ochrona klimatu i różnorodności biologicznej nie zawsze ida ze soba $w$ parze. $Z$ drugiej strony, elementy te sa od siebie zależne i aby chronić jedno, nie możemy pozostawać obojętni wobec drugiego. Czy warto poświęcać przyrodnicze i kulturowe dziedzictwo dla wydobycia pierwiastka, którego wykorzystanie może potencjalnie złagodzić negatywne skutki zmian klimatycznych, czy też należy szukać dalszych rozwiąań? Być może szkodliwa środowiskowo ingerencja w ekosystem Atakamy to cena, jaka musimy zapłacić, by zapobiec jeszcze bardziej szkodliwym zmianom w skali globalnej. Może jednak okazać się, że to po prostu tymczasowe rozwiazanie już dawno zdiagnozowanego i długo ignorowanego problemu klimatycznego, które przyczyni się wyłącznie do doraźnego zakamuflowania objawów, kosztem kolejnego elementu naturalnego i kulturowego dziedzictwa ludzkości. Należy zatem szukać bardziej holistycznych rozwiazań, które pozwola w efektywny sposób chronić zarówno klimat, jak i różnorodność biologiczną. Stanowi to duże wyzwanie, ale jest to również szansa na zrównoważony rozwój biznesu, turystyki, nauki i nowych technologii, tym razem przy poszanowaniu przyrody i rządzących nia praw.

\section{Streszczenie}

Wykorzystanie energii elektrycznej w transporcie stanowi jedna $z$ wielkich nadziei $w$ walce ze zmianami klimatycznymi. Budowa samochodów elektrycznych wymaga jednak znacznych ilości litu, pierwiastka, którego największe na świecie rezerwuary znajduja się na pustyni Atakama w północnym Chile. Wpływ górnictwa na ten obszar pozostaje słabo udokumentowany. Biorac pod uwage przyrodnicza, kulturowa i naukowa wartość Atakamy należy zredefiniować dotychczasowe podejście do potencjalnych korzyści i zagrożeń wynikających z eksploatacji chilijskich złóż litu. Walory florystyczne, 
faunistyczne i geologiczne Atakamy współtworza bowiem wrażliwy na ingerencję ekosystem, który w obliczu postępujących zmian klimatycznych powinien być otoczony szczególna troską. Do tej pory jednak polityka i gospodarka marginalizowały działania związane $z$ ochrona przyrody. Wzrost świadomości społecznej zwiazanej $z$ procesem produkcji baterii litowych powinien iść $\mathrm{w}$ parze $z$ intensyfikacja prac nad szerokim zakresem działań kompensacyjnych oraz zwiększeniem możliwości recyklingu baterii litowych.

\section{LITERATURA}

BABIDGE S., 2016. Contested value and an ethics of resources: Water, mining and indigenous people in the Atacama Desert, Chile. Austral. J. Anthropol. 27, 84-103.

BlOMGREN G. E., 2016. The development and future of lithium ion batteries. J. Electrochem. Soc. 164, https://iopscience.iop.org/article/10.1149/2.0251701jes/meta.

DuArte M., Guerrero P. C., Arroyo M. T. K., Bustamante R. O., 2019. Niches and climate-change refugia in hundreds of species from one of the most arid places on Earth. PeerJ 7, https://peerj.com/articles/7409.

Flint S., TURner P., Jolley E. J., HaRTley A. J., 1993. Extensional tectonics in convergent margin basins: An example from the Salar de Atacama, Chilean Andes. GSA Bulletin 105, 603-617.

GEBICA P., 2010. Walory krajobrazowe Andów $i$ ich wykorzystanie $w$ turystyce, na przykładzie Peru, Chile i Boliwii. Prace Komisji Krajobrazu Kulturowego 14, 74-90.

Gruber P. W., Medina P. A., Keoleian G. A., KeSLER S. E., EVERSON M. P., WALLINGTON T. J., 2011. Global lithium availability. J. Industr. Ecol. 15, 760-775.

HOUSTON J., 2006. Variability of precipitation in the Atacama Desert: its causes and hydrological impact. Int. J. Climatol. 26, 2181-2198.

JORDAN T. E., ISACKS B. L., ALlMENDingeR R. W., BRewer J. A., Ramos V. A., ANDO C. J., 1983. Andean tectonics related to geometry of subducted Nazca plate. GSA Bulletin 94, 341-361.
Kesler S. E., Gruber P. W., Medina P. A., KeOlEIAN G. A., EVERSON M. P., WALlingtON T. J., 2012. Global lithium resources: Relative importance of pegmatite, brine and other deposits. Ore Geol. Rev. 48, 55-69.

MoRTIMER C., 1973. The Cenozoic history of the southern Atacama Desert, Chile. J. Geol. Soc. 129, 505-526.

ORTEGA-BAES P., SÜHRING S., SAJAMA J., SOTOlA E., Alonso-Pedano M., Bravo S., Godínez-AlVAREZ H., 2010. Diversity and conservation in the cactus family. [W:] Desert Plants: Biology and Biotechnology. RAMAWAT K. G. (red.). Springer, Berlin, Heidelberg, 157-173.

Parro V., DE Diego-Castilla G., Moreno-Paz M., Blanco Y., CRUZ-Gil P., Rodríguez-MANFREDI J. A., FERNÁNDEZ-REMOlaR D., GómEZ F., Gómez M. J., Rivas L. A., DEMERGasso C., ECHEVERRÍA A., URTUVIA V. N., RUIZ-BERMEJO M., García-Villadangos M., Postigo M., SánCHEZ-ROMÁN M., CHONG-DíAZ G., GÓMEZ-ElviRA J., 2011. A microbial oasis in the hypersaline Atacama subsurface discovered by a life detector chip: implications for the search for life on Mars. Astrobiology 11, 969-996.

PAulo A., 2002. Chañarcillo (Puna de Atacama, Chile) jako geologiczne stanowisko dokumentacyjne $i$ zabytek górnictwa zwiazany $z$ Domeyka. Przegląd Geologiczny 50, 496-505.

PRADO B., DEL MORAL A., CAMPOS V., 1993. Distribution and types of heterotrophic halophilic flora from Salar de Atacama, Chile. Toxicol. Environ. Chem. 38, 163-166.

QuinN R. C., ZENT A. P., GRUNTHANER F. J., EHRENFREUND P., TAYLOR C. L., GARRY J. R. C., 2005. Detection and characterization of oxidizing acids in the Atacama Desert using the Mars Oxidation Instrument. Planet. Space Sci. 53, 1376-1388.

Romero H., MÉndeZ M., Smith P., 2012. Mining development and environmental injustice in the Atacama Desert of Northern Chile. Environ. Justice 5, 70-76.

VIKSTRÖM H., DAVIDSSON S., HÖÖK M., 2013. Lithium availability and future production outlooks. Appl. Energy 110, 252-266.

WiCKENS G. E., 1995. Llareta (Azorella Compacta, Umbelliferae): A review. Econo. Bot. 49, 207212. 
KOSMOS Vol. 70, 1, 9-18, 2021

Sonia Paź-Dyderska ${ }^{1}$, MARcin K. Dyderski ${ }^{1}$, ANDRZEJ M. JAGODZińSKI ${ }^{1,2}$

${ }^{1}$ Institute of Dendrology PAS, 5 Parkowa Str., 62-035 Kórnik, ${ }^{2}$ Department of Game Management and Forest Protection, Faculty of Forestry and Wood Technology, Poznań University of Life Sciences, 71D Wojska Polskiego Str., 60-625 Poznań,

E-mail: sdyderska@man.poznan.pl, mdyderski@man.poznan.pl,amj@man.poznan.pl

CLIMATE PROTECTION OVER BIODIVERSITY CONSERVATION? ENVIRONMENTAL AND SOCIAL CONSEQUENCES OF LITHIUM MINING IN THE ATACAMA DESERT

\section{Summary}

The use of electricity in transport is one of the great hopes in the fight against climate change. However, electric cars require significant amounts of lithium, an element which the world's largest reservoirs are in the Atacama Desert in northern Chile. The impact of mining in this area remains poorly recognized. Taking into account Atacama's natural, cultural and scientific value, it is crucial to redefine the current assessment of the potential benefits and threats resulting from the exploitation of lithium deposits. The Atacama's floristic, faunistic and geological values co-create an ecosystem sensitive to interference, which should be treated with special care under changing climate. Until now, however, politics and the economy have marginalized nature protection activities. Social awareness increase related to the lithium battery production should go hand in hand with the intensification of work on the wide use of compensation actions and increasing the recycling capacity of lithium batteries.

Key words: Atacama, batteries, Chile, electric cars, lithium 